\title{
Diet of Atlantic lizardfish, Synodus saurus (Linnaeus, 1758) (Pisces: Synodontidae) in the central Mediterranean Sea
}

\author{
VALENTINA ESPOSITO ${ }^{1}$, PIETRO BATTAGLIA ${ }^{1}$, LUCA CASTRIOTA ${ }^{2}$, \\ MARIA GRAZIA FINOIA ${ }^{3}$, GIANFRANCO SCOTTI $^{1}$ and FRANCO ANDALORO ${ }^{2}$ \\ ${ }^{1}$ ISPRA-ex ICRAM (High Institute for Environment Protection and Research), Laboratory of Milazzo, Via dei Mille 44, \\ 98057 Milazzo (ME), Italy. E-mail: espositovalentina@hotmail.com \\ 2 ISPRA-ex ICRAM, STS Palermo, c/o Marbela Residence, Via Salvatore Puglisi 9, 90143 Palermo, Italy. \\ ${ }^{3}$ ISPRA-ex ICRAM, via di Casalotti 300, 00166 Roma, Italy.
}

\begin{abstract}
SUMMARY: The diet composition of the Atlantic lizardfish Synodus saurus, caught on sandy bottoms of the north-western coast of Sicily (southern Tyrrhenian Sea) is described. The stomachs of 224 specimens (from 73 to $280 \mathrm{~mm}$ TL) were collected between June 2005 and May 2006. The analysis of stomach contents showed that this species is almost exclusively piscivorous. Unlike other benthic predators of the study area, it mainly feeds on pelagic school-forming fish, such as Clupeidae, Engraulidae and Myctophidae and juveniles of Sparidae and Centracanthidae, and benthic prey play a secondary role. The diet of $S$. saurus is related to the seasonal availability of resources, depending on the occurrence of juveniles of several species and on the migration of pelagic fishes in the study area. There were no significant changes in prey items between predator length groups, but a positive, significant linear relationship between prey size and predator size was recorded.
\end{abstract}

Keywords: diet, feeding habits, Synodontidae, Synodus saurus, ontogeny, central Mediterranean Sea, Sicily.

\begin{abstract}
RESUMEN: Dieta del pez de San Francisco Synodus saurus (Linnaeus, 1758) (Pisces: Synodontidae) en el MediTERRÁNEO CENTRAL. - El presente trabajo ha estudiado la composición de la dieta del pez de San Francisco Synodus saurus, pescado sobre fondos arenosos en la costa nor-occidental de Sicilia (Tirreno meridional). El análisis del contenido estomacal de 224 individuos (entre 73 y $280 \mathrm{~mm} \mathrm{LT}$ ), pescados entre junio 2005 y mayo 2006, evidenció que $S$. saurus es una especie casi exclusivamente ictiófaga. A diferencia de otros depredadores bentónicos, $S$. saurus se alimenta fundamentalmente de peces que forman bancos pelágicos como Clupeidae, Engraulidae y Myctophidae y de los juveniles de las familias Sparidae y Centracanthidae, mientras las presas bentónicas resultaron secundarias. S. saurus exhibió una estrategia alimentaria relacionada con la disponibilidad estacional de recursos, dependiendo de la ocurrencia de juveniles de varias especies y de la migración de peces pelágicos en el área de estudio. No hubo cambio significativo de presas entre grupos de tallas pero se evidenció una relacción positiva, lineal y estadísticamente significativa entre el tamaño de la presa y del depredador.
\end{abstract}

Palabras clave: dieta, ecología trófica, Mediterráneo central, ontogenia, Synodontidae, Synodus saurus, Sicilia.

\section{INTRODUCTION}

The Atlantic lizardfish, Synodus saurus (Linnaeus, 1758), is an epibenthic subtropical fish belonging to the Synodontidae family, distributed in the Mediterranean Sea, the eastern Atlantic from
Morocco to Cape Verde, including the Azores, and the western Atlantic from Bermuda and the Bahamas to the Lesser Antilles (Leeward Islands) (Sulak, 1986; Bauchot, 1987). In the Mediterranean, this species can reach a total length of $43 \mathrm{~cm}$ (Bauchot, 1987) and is commonly found on sandy bottoms, 
primarily at depths less than $50 \mathrm{~m}$ with occasional records of $400 \mathrm{~m}$ (Sulak, 1986; Bauchot, 1987). It is a dioecious species and its spawning period falls within the spring and summer months, with a reproductive peak in July, both in the Atlantic Ocean (Sousa et al., 2003) and the Mediterranean Sea (Golani, 1993).

Synodus saurus, like others of the Synodontidae family, is characterised by immobile and camouflage behaviour (Keenleyside, 1979; Sulak, 1986; Golani, 1993; Kagiwara and Abilhôa, 2000). Despite spending most of its time buried in the sand, the lizardfish is a highly mobile predator that can also capture pelagic fishes in midwater (Soares et al., 2003). Soares et al. (2002) made underwater observations of the predatory behaviour of S. saurus in Azorean waters and found that lizardfish compete for territory through intraspecific agonistic interactions and occasionally through non-agonistic interspecific relations (e.g. with Bothus podas maderensis).

The diet and feeding behaviour of Synodus saurus in the Atlantic Ocean have been exhaustively described (Soares et al., 2002, 2003); however, very little is known about these in the Mediterranean Sea. Currently Golani (1993) has made the only study, but it was based on a very low number of individuals from the Israeli coast.

The purpose of this study is to analyse the diet and feeding habits of Synodus saurus in the southern Tyrrhenian Sea (central Mediterranean) in different periods of the year, at different depths and in different size classes.

\section{MATERIALS AND METHODS}

Synodus saurus were collected by bottom trawl in the southern Tyrrhenian Sea, along the northern Sicilian coast, on the sandy bottoms located in an area between Capo d'Orlando and Capo Calavà (Fig. 1).

From June 2005 to May 2006, four trawl surveys were carried out during daylight hours (from 8 a.m. to 4 p.m.), using a net with a codend mesh-size of 20 $\mathrm{mm}$. In each survey, 2 hauls of $20 \mathrm{~min}$ at an average speed of 2.8 knots were conducted at three depths $(10,20$ and $30 \mathrm{~m})$ for a total of 24 hauls during the entire study period.

A total of 224 individuals of Synodus saurus was measured (total length TL) to the nearest millimetre, weighed to the nearest $0.1 \mathrm{~g}$ and their stomachs removed and preserved in $70 \%$ ethanol.

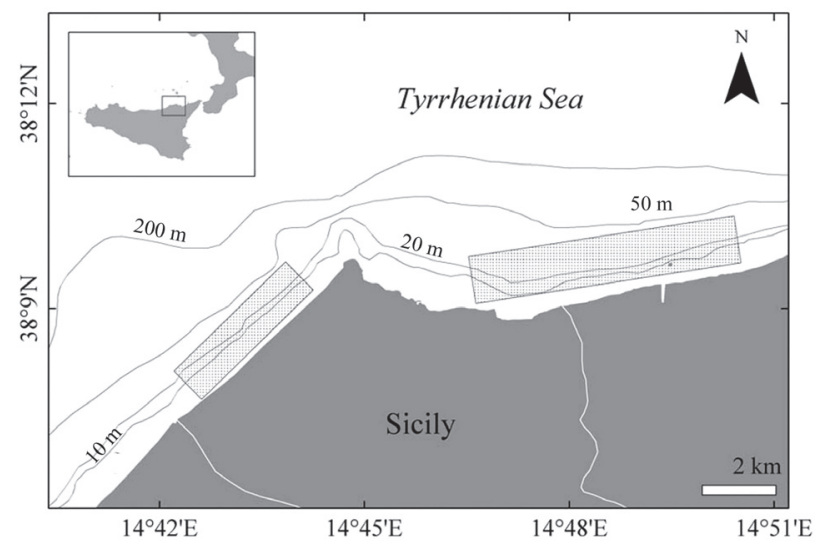

FIG. 1. - Study area, showing sampling stations.

Sorting was carried out under a binocular microscope and prey items were identified to the lowest possible taxon and counted and weighed to the nearest $0.1 \mathrm{mg}$, after removing excess water with blotting paper. The vacuity coefficient $(\mathrm{V} \%=$ percent of empty stomachs) was calculated. Fish prey were classified according to their life stage. When found entire, prey items were measured to the nearest 0.1 $\mathrm{mm}$ TL with a caliper.

The cumulative number of new prey types was plotted against the cumulative number of non-empty stomachs analysed in order to measure sample size sufficiency (Ferry and Caillet, 1996). The PRIMER software was used to compute a prey species accumulation plot as an average of 999 curves based on different random orders of the stomachs. The standard deviation was calculated and represented in a graph for every five stomachs. The logistic and the linear regressions were calculated and the goodness of fit coefficient $\mathrm{R}^{2}$ compared: the sample size was considered sufficient when $\mathrm{R}^{2}$ for the logistic curve was higher than $\mathrm{R}^{2}$ for the linear relation (Castriota et al., 2005a).

The contribution of different prey items to the diet of Synodus saurus was estimated by calculating the abundance percentage $(\% \mathrm{~N}=$ number of prey $i /$ total number of prey $* 100)$ and weight percentage $(\% \mathrm{~W}$ $=$ weight of prey $i$ / total weight of all prey $* 100$ ) (Pinkas et al., 1971; Hyslop, 1980; Hacunda, 1981).

To assess potential diet changes with respect to sampling periods and depths, abundance (a) and biomass (b) data were analysed by means of a multivariate analysis of similarities (ANOSIM). This analysis was based on Gower distances and was performed on 22 prey categories after the data had been square root transformed. Pair-wise a posteriori comparisons were computed after significant differences $(p<0.05)$ among factor levels were detected. 
TABLE 1. - Abundance percentage $(\% \mathrm{~N})$ and weight percentage $(\% \mathrm{~W})$ for prey items of S. saurus. Total values are given in bold print.

\begin{tabular}{|c|c|c|c|c|c|}
\hline & $\% \mathrm{~N}$ & $\% \mathrm{~W}$ & & $\% \mathrm{~N}$ & $\% \mathrm{~W}$ \\
\hline VERTEBRATA Teleostei & & & Clupeidae & 1.4 & 21.2 \\
\hline SPARIDAE & 12.3 & 25.5 & Sardina pilchardus & 0.7 & 8.9 \\
\hline Pagellus acarne (juv) & 3.6 & 14.4 & Sardinella aurita & 0.7 & 12.3 \\
\hline Boops boops (juv) & 7.2 & 10.8 & ENGRAULIDAE & 7.2 & 8.0 \\
\hline Unid. Sparidae (juv) & 1.4 & 0.3 & Engraulis encrasicolus & 7.2 & 8.0 \\
\hline Centracanthidae & 6.5 & 5.2 & Unid. Clupeiformes & 0.7 & 1.2 \\
\hline Spicara sp. (juv) & 4.3 & 0.4 & BOTHIDAE & 1.4 & 0.4 \\
\hline Spicara smaris (juv) & 0.7 & 2.1 & Arnoglossus thori (juv) & 1.4 & 0.4 \\
\hline Spicara maena (juv) & 1.4 & 2.7 & TRIGLIDAE & 0.7 & 6.8 \\
\hline AMMODYTIDAE & 1.4 & 0.3 & Lepidotrigla cavillone & 0.7 & 6.8 \\
\hline Gymnammodytes cicerelus (juv) & 1.4 & 0.3 & & & \\
\hline GOBIIDAE & 5.1 & 1.7 & Unid. Teleostei & 48.6 & 26.2 \\
\hline Deltentosteus quadrimaculatus & 2.9 & 1.1 & VERTEBRATA Teleostei total & 94.2 & 99.7 \\
\hline Unid. Gobiidae & 2.2 & 0.6 & & & \\
\hline CALLYONIMIDAE & 2.2 & 1.8 & ANNELIDA & & \\
\hline Callyonimus sp. & 2.2 & 1.8 & Polychaeta Serpulidae & 0.7 & $<0.1$ \\
\hline МYCTOPHIDAE & 6.5 & 1.5 & ANNELIDA total & 0.7 & $<0.1$ \\
\hline Ceratoscopelus maderensis & 4.3 & 0.8 & & & \\
\hline Hygophum benoiti & 1.4 & 0.7 & & & \\
\hline Unid. Myctophidae & 0.7 & $<0.1$ & SPERMATOPHYTA Cymodocea nodosa & 7.2 & 0.3 \\
\hline
\end{tabular}

A multivariate multiple permutation test (SIMPER) was used to establish the contribution of each prey category to the average within-group similarity and dissimilarity between groups in terms of BrayCurtis similarities. These analyses were performed using the statistical software PRIMER 6 (Plymouth Routines In Multivariate Ecological Research) (Clarke and Warwick, 2001).

A correspondence discriminant analysis (CDA) was used with prey abundance data to separate prey items in relation to study periods and depths. This analysis was developed to analyse ecological data and is appropriate for comparing individuals belonging to several groups. It is particularly useful for describing how groups differ in terms of variables (Chessel and Thioulouse, 1996). CDA was repeated to classify prey items into 4 predator size classes (<158 mm; 158-196 mm; 196-217 mm; >217 mm) obtained by dividing the length frequency distribution of Synodus saurus into quartiles. CDA was computed with the ADE-4 software package.

Linear regression analysis was performed using SPSS software to assess the relationship between prey size and predator size. In addition, to examine the pattern of relative prey size of Synodus saurus, a relative frequency histogram of prey-size/predator size ratios was generated.

\section{RESULTS}

Of the total 224 stomachs analysed, 101 contained food $(\mathrm{V} \%=45)$. The length-frequency distribution

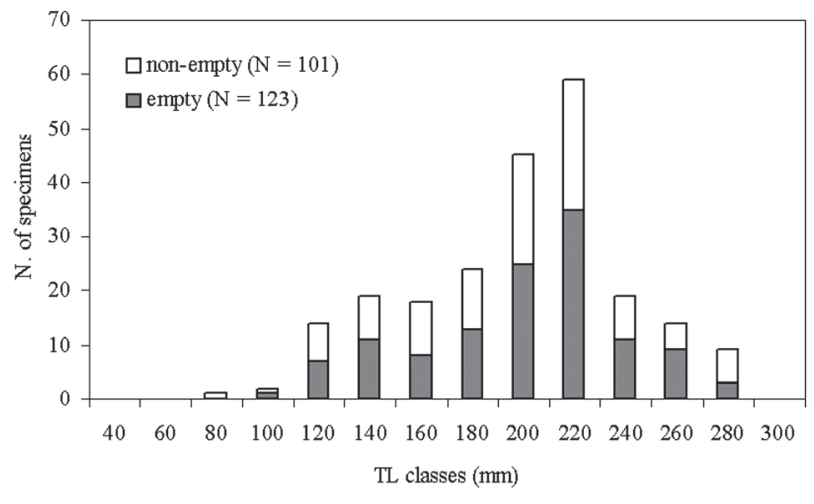

FIG. 2. - Length frequency distribution of specimens of $S$. saurus with empty and non-empty stomachs.

of samples with empty and non-empty stomachs for $20 \mathrm{~mm}$ total length (TL) classes is shown in Figure 2; specimens ranged from 73 to $280 \mathrm{~mm}$ TL and were almost equally distributed in all size classes, with a predominance of lengths between 200 and $220 \mathrm{~mm}$.

The cumulative prey type curve (Fig. 3) for the entire data set fitted a logistic curve $\left(\mathrm{R}^{2}=0.983\right.$, $\left.\mathrm{F}_{(1,99)}=2974.4, \mathrm{p}<0.001\right)$ better than a linear relation $\left(\mathrm{R}^{2}=0.866, \mathrm{~F}_{(1,99)}=640.3, \mathrm{p}<0.001\right)$; therefore, the sample size was considered sufficient for describing the diet of the Atlantic lizardfish.

The prey items and their respective $\% \mathrm{~N}$ and $\% \mathrm{~W}$ values are reported in Table 1. 22 prey categories were recorded. Teleosts (mostly juveniles) attained a numerical percentage of $94.2 \%$ and accounted for a weight percentage of $99.7 \%$ of the total weight. 10 families were identified among the teleosts: according to all numerical indicators, sparids were dominant, and were mainly represented by juveniles 


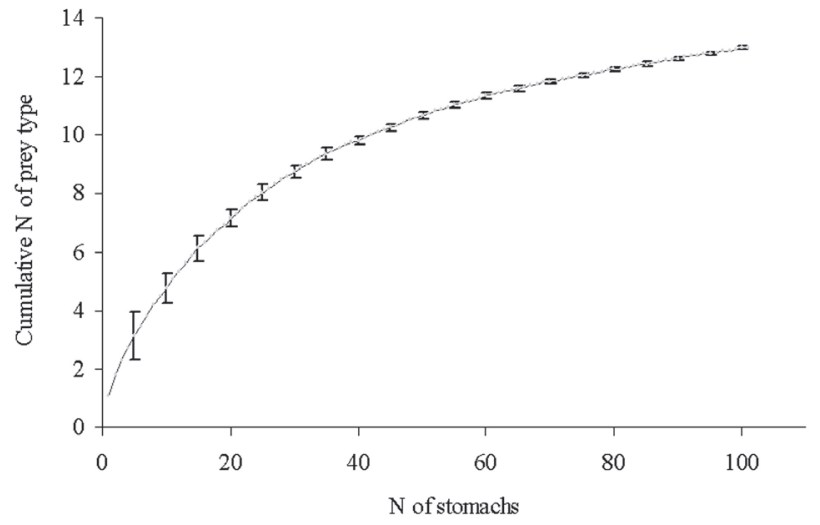

Fig. 3. - Prey species accumulation plot as an average of 999 curves based on different random orders of the stomachs extracted (n. of stomachs $=101)$. Vertical bars represent standard deviation.

of Boops boops and Pagellus acarne; engraulids and mictophids were also important in terms of $\mathrm{N} \%$ while clupeids were accounted for mainly in $\mathrm{W} \%$. Teleosts were generally present in a highly digested state and as unidentifiable remains, and account for the highest percentage of unidentified fish among prey items. Serpulids was the sole invertebrate prey and was only found once.

The results of the ANOSIM test performed on abundance and biomass data showed that the diet of the species was not affected by depth, while there were significant differences between the sampling periods in terms of both prey abundance $\left(\right.$ global $\mathrm{R}_{\mathrm{a}}=$ 0.068 ) and prey biomass (global $R_{b}=0.08$ ). In particular, the diet of the specimens caught in June 05 and in October 05 differed significantly from that of the

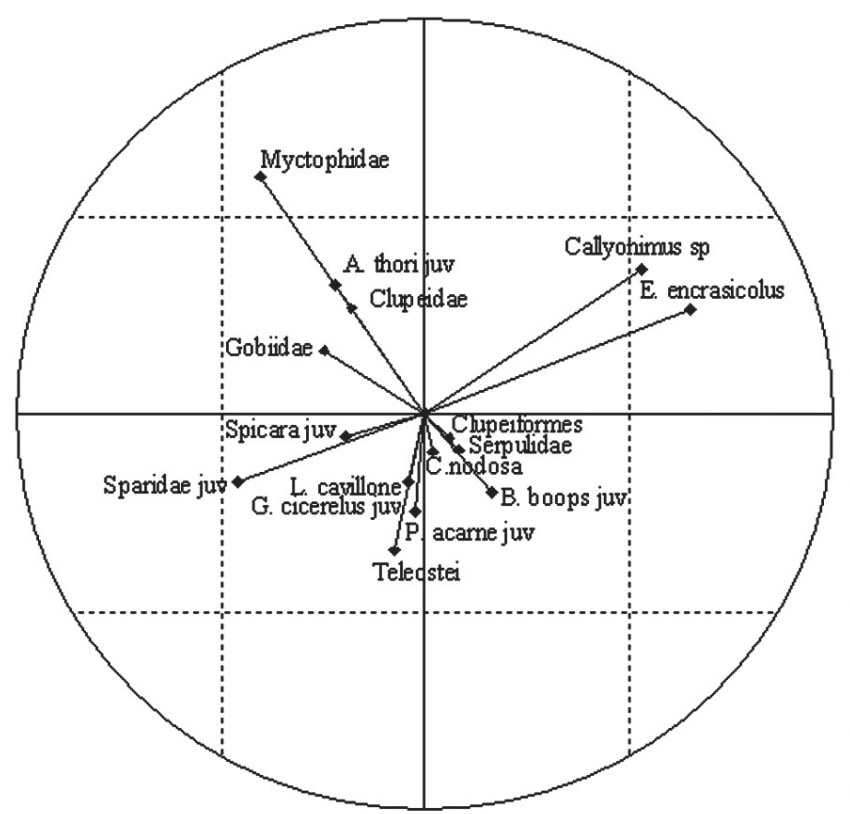

FIG. 4 - Correspondence discriminant analysis (CDA) computed for study periods explaining $83.8 \%$ of the total variance.

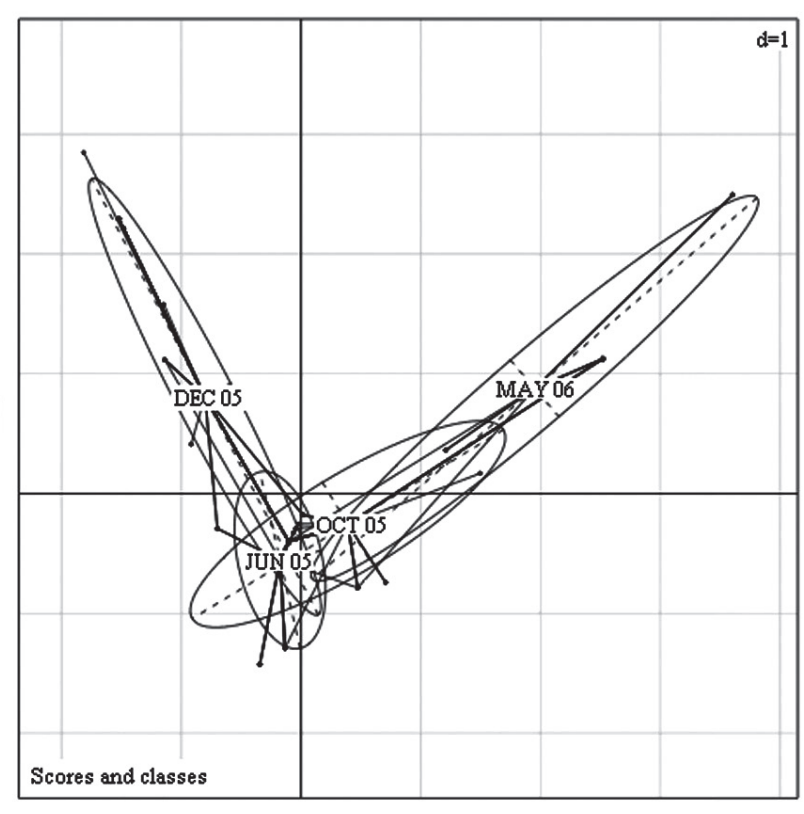

specimens caught in December $05\left(\mathrm{R}_{\mathrm{a}}=0.102\right.$ and $\mathrm{R}_{\mathrm{a}}=0.107$ respectively; $\mathrm{R}_{\mathrm{b}}=0.097$ and $\mathrm{R}_{\mathrm{b}}=0.068$ respectively). The results of the SIMPER analysis showed that the average similarity between samples of the same period (group) in all cases was $<50 \%$, which evidences the opportunistic behaviour of this species. The highest average similarity was found within the specimens caught in June, with mainly Pagellus acarne juveniles contributing to their diet. The high dissimilarity found between the June and December groups $\left(\delta_{\mathrm{a}}=81.4 \%\right.$ and $\left.\delta_{\mathrm{b}}=81.2 \%\right)$ is imputable to the absence of $P$. acarne juveniles and the occurrence of the mictophid Ceratoscopelus maderensis in the December samples. The high dissimilarity between the October and December groups $\left(\delta_{a}=87.1 \%\right.$ and $\left.\delta_{b}=86.7 \%\right)$ is due to Myctophidae only occurring in December, and Engraulis encrasicolus and Boops boops only occurring in October.

CDA computed for study periods explained $83.8 \%$ of the total variance and clearly separated the individuals of Synodus saurus caught in June-December from those caught in October-May. Prey items that were responsible for the differences were Engraulis encrasicolus, which was predominantly predated in October, Callyonimus sp. predated mainly in May, Myctophidae, Arnoglossus thori juveniles, Clupeidae and Gobiidae predated in December and Lepidotrigla cavillone, Gymnammodytes cicerelus and Pagellus acarne juveniles in June (Fig. 4).

The CDA computed for depths explained $100 \%$ of the total variance and did not show a clear separation

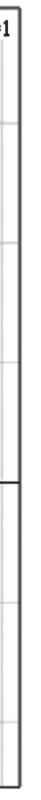

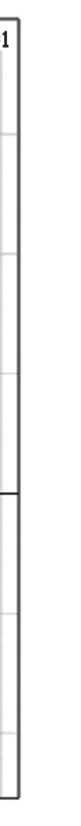



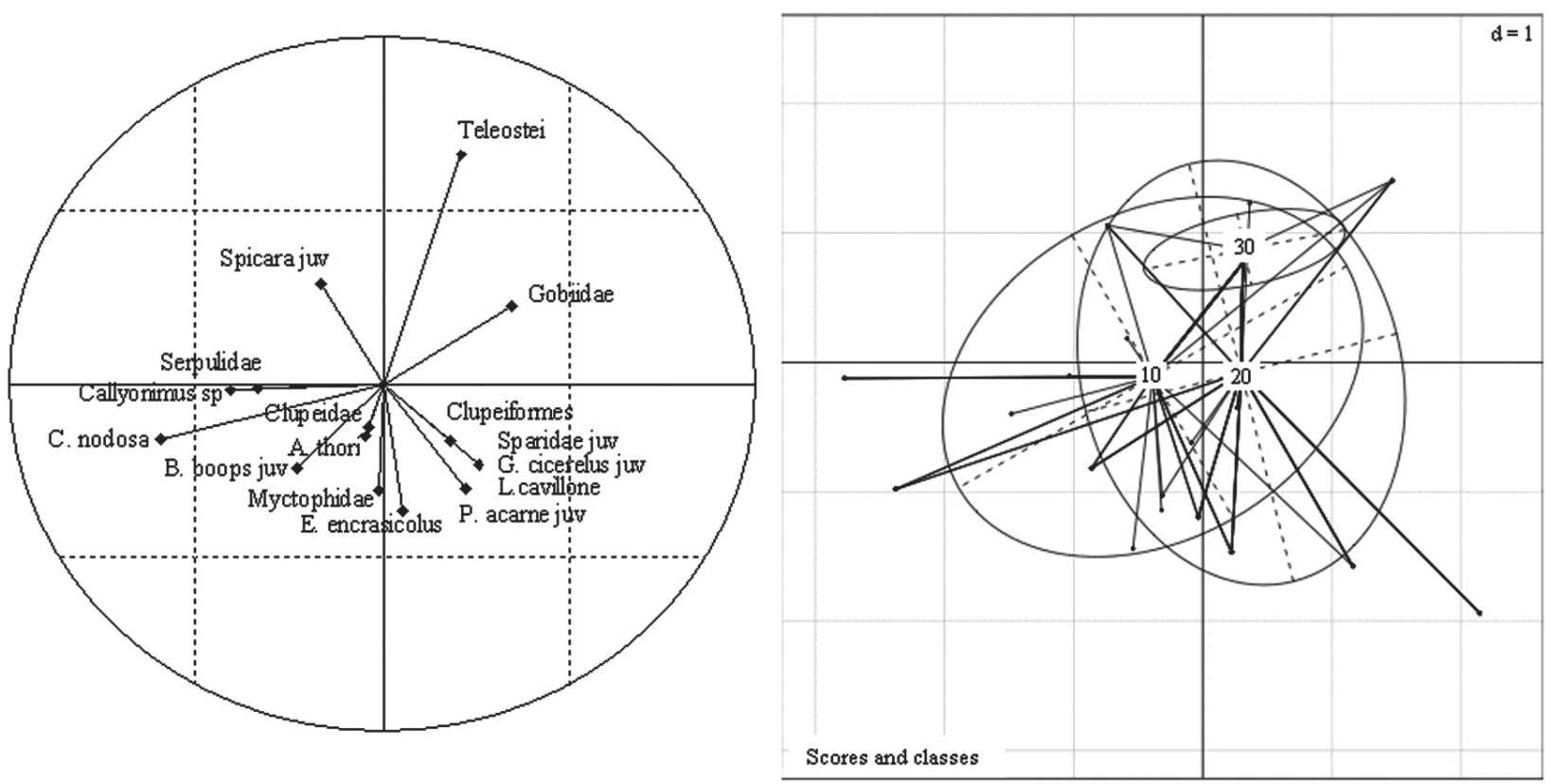

FIG. 5 - Correspondence discriminant analysis (CDA) computed for depth explaining $100 \%$ of the total variance.

of prey items. Callyonimus sp, Cymodocea nodosa and Serpulidae were distributed towards the $10 \mathrm{~m}$ bathymetry; Clupeiformes, Engraulis encrasicolus, Pagellus acarne juv, Gymnammodytes cicerelus juv, Lepidotrigla cavillone and Sparidae juv were found at a depth of $20 \mathrm{~m}$; Gobiidae were typical at the 30 m bathymetry (Fig. 5).

The CDA computed for size classes explained $77.4 \%$ of the total variance and revealed that Myc- tophidae and Arnoglossus thori juveniles were mainly predated by the smallest specimens of lizardfish $(<158 \mathrm{~mm})$, Engraulis encrasicolus, Boops boops and Pagellus acarne juveniles by the intermediate predator size classes $(158-217 \mathrm{~mm})$ and Clupeidae and Spicara juveniles by the largest ones $(>217 \mathrm{~mm})$ (Fig. 6).

Of the 101 individuals of Synodus saurus with non-empty stomachs, 48 specimens, ranging from
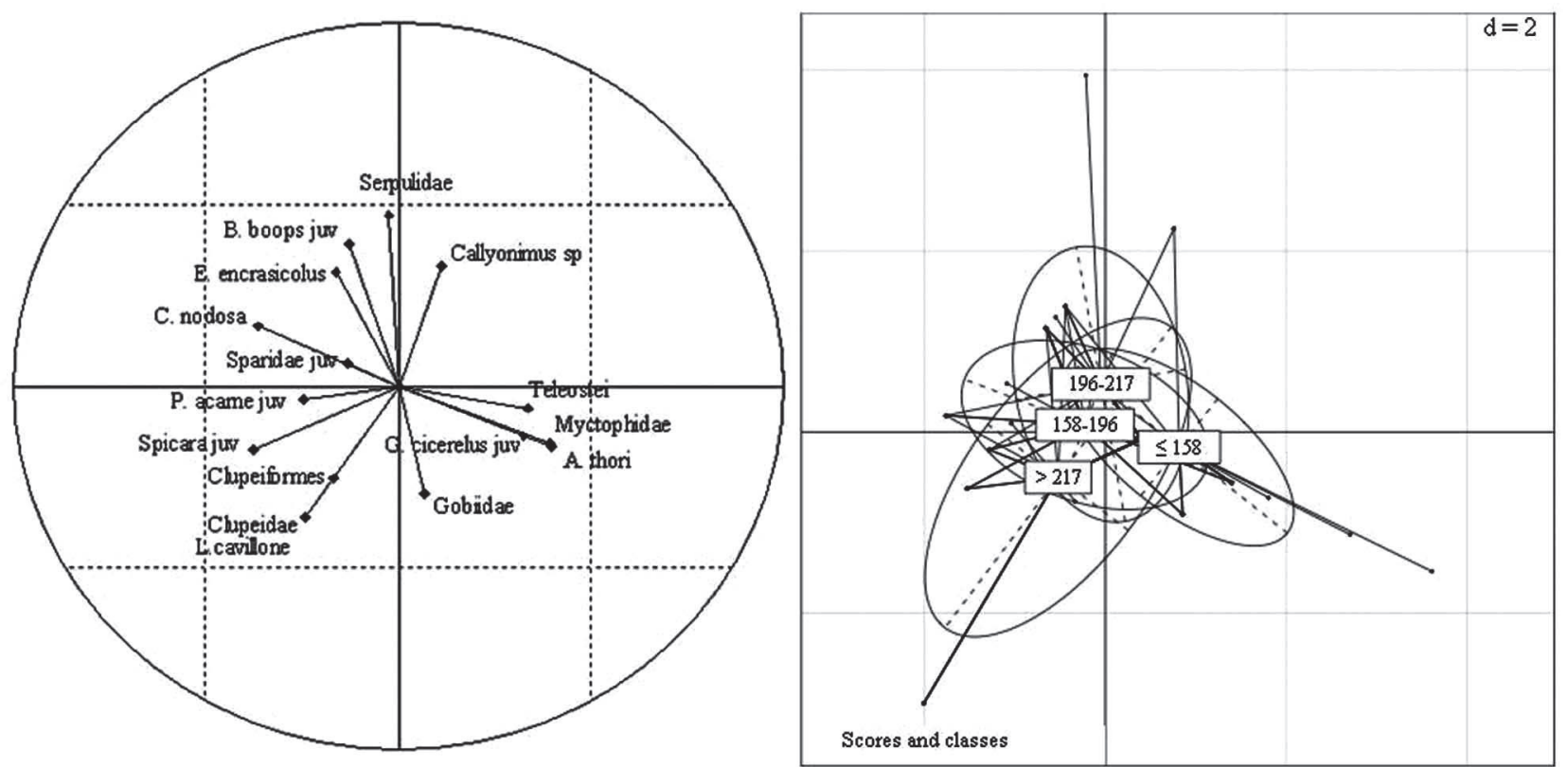

FIG. 6 - Correspondence discriminant analysis (CDA) computed for predator size classes explaining $77.4 \%$ of the total variance 


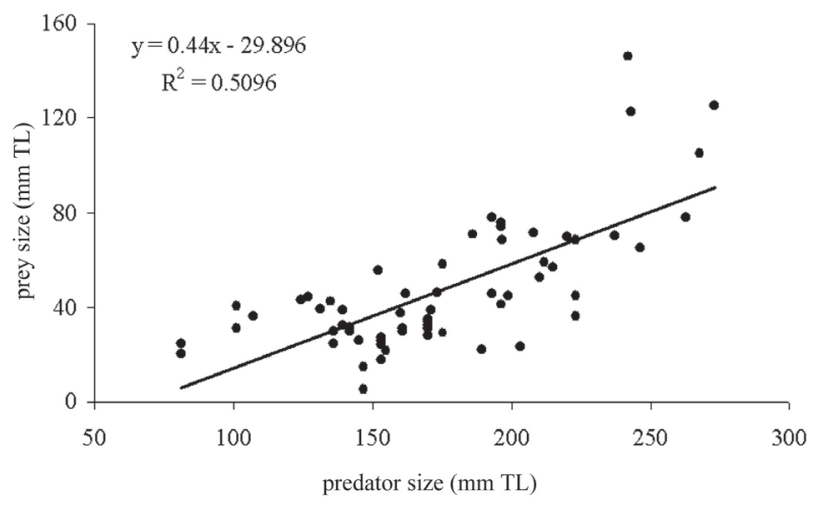

FIG. 7 - Prey size-predator size relationship.

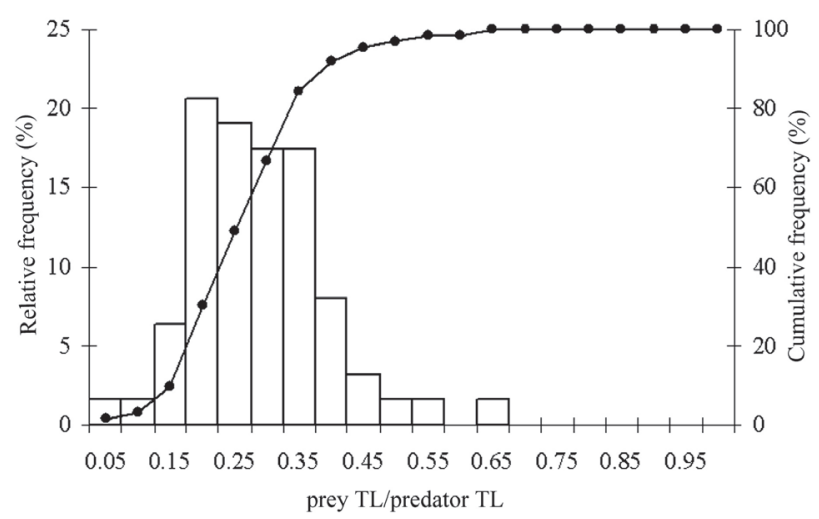

FIG. 8 - Relative frequency distribution of prey size/predator size ratios consumed by $S$. saurus. Cumulative frequency is indicated by a continuous line with filled circles at $5 \%$ intervals of prey size/ predator size ratios.

81 to $273 \mathrm{~mm}$ TL, had 63 entire prey items, among which clupeids were the largest prey. The results of the linear regression analysis (Fig. 7) showed a positive and significant linear relationship $\left(\mathrm{r}=0.7, \mathrm{~F}_{(1,61)}\right.$ $=63.38, \mathrm{p}<0.05)$ between prey size and predator size. The relative frequency histogram of prey-size/ predator size ratios (Fig. 8) showed that nearly $84 \%$ of the diet of $S$. saurus was made up of prey with a body size $<35 \%$ of the predator body size.

\section{DISCUSSION}

Atlantic lizardfish is considered to be an epibenthic cryptic predator that feeds primarily on small gregarious pelagic fish but also on crustaceans and cephalopods (Golani, 1993; Soares et al., 2002, 2003). In our study area, this species was found to be almost exclusively piscivorous with the ability of exploring different habitats and capturing different prey types. Synodus saurus feeds on benthic fishes of the families Callionymidae, Gobiidae, Bothidae and Triglidae that occupy the same habitat as it, and also on gregarious pelagic fishes of the Clupeidae and Engraulidae families, on juveniles of Sparidae and Centracanthidae which occur periodically in coastal waters and on mesopelagic fishes (Myctophidae) which migrate to shallow layers at night (Scotto di Carlo et al., 1982). According to Soares et al. (2003) and Golani (1993), benthic fishes have a secondary role in the diet of Synodus saurus in comparison to other fishes, as demonstrated by the $\% \mathrm{~N}$ indexes. Conversely, Engraulis encrasicolus and juveniles of Sparidae were the major components of the diet of $S$. saurus in the southern Tyrrhenian sea; among the Sparidae, Pagellus acarne and Boops boops, which are commonly recorded in the study area (Andaloro, 2008), dominated. Golani (1993) also pointed out the importance of B. boops in the diet of the Atlantic lizardfish in eastern Mediterranean waters, while Soares et al. (2003) found that the main food resources were Sardina pilchardus and Sphyraena viridensis in Azorean waters.

In all study periods, about half the sampled specimens of Synodus saurus had empty stomachs; as sampling was carried out in the daytime, we can suppose that this species feeds at different times during the 24 hours of the day. Nocturnal feeding is also suggested by the occurrence of myctophids in some stomachs. However, the high vacuity index found may be biased because of the method employed to catch the specimens (i.e. trawling) that would cause regurgitation in some individuals, thus leading to underestimations of diurnal feeding.

The diversity of prey of Tyrrhenian Synodus saurus caught in the different periods of the year seems to reflect the periodical occurrence of certain species in the study area. Such a correspondence would confirm the opportunistic behaviour of this predator, whose diet depends on the different resource availability in the area, which has also been observed for other Synodus species elsewhere (Cruz-Escalona et al., 2005).

In particular, the contribution of Pagellus acarne and Spicara spp. juveniles to the diet of Synodus saurus was important during spring, while Boops boops juveniles and Engraulis encrasicolus were mainly predated in autumn then replaced by myctophids in late autumn-early winter. This pattern is consistent with the seasonal succession of species abundance recorded in the study area (our trawl surveys and commercial landings), and is also confirmed by data from the literature from nearby 
areas (Montalenti, 1937; Scotto di Carlo et al., 1982; Matarrese et al, 1996).

The occurrence of lanternfish in autumn-winter, is probably related to the major mixing of water layers in the absence of a thermocline; the presence of this transition layer seems to influences the vertical distribution of some mesopelagic fishes (Paxton, 1967). The particular bottom morphology in the study area, together with the presence of submarine valleys and canyons, a narrow continental shelf and a very steep slope (Andaloro, 1994; Brambati et al., 1995; Tramontana et al., 1995), also facilitate the upward migration of mesopelagic organisms making them available to coastal predators. The predation of Atlantic lizardfish on mesopelagic species therefore plays an important role in the energy transfer and recycling from deep to coastal waters.

Soares et al. (2003) found that Synodus saurus exhibited a size-based feeding strategy, as its diet, regardless of the length of the predator, was concentrated on juveniles or prey species with a body size $<35 \%$ of the predator body size.

However, whereas these authors did not find any positive relation between prey size and predator size, in our study we found that as the predator grew prey sizes significantly increased. According to Soares et al. (2003) a significant change of prey items did not correspond to such a size-related ontogenetic shift. We observed that small prey, such as Myctophidae and the flatfish Arnoglossus thori juveniles, were more frequent in the stomach contents of smaller predators than in those of larger predators, where, conversely, bigger prey, such as Clupeidae, were more commonly found. Therefore, in addition to resource availability, prey size seems to strongly influence the feeding behaviour of this predator; however, according to the low discrimination of prey items across depths, this factor does not affect its food choices.

The specialised sit-and-wait predatory behaviour of the Atlantic lizardfish also allows it to hunt pelagic school-forming fish, which are not usually preyed upon by other benthic predators. Studies on the feeding habits of predators (Xyrichtys novacula, Mullus barbatus, Bothus podas) living in the same area, have clearly shown their preferences for benthic invertebrates (Castriota et al., 2005a, 2005b, 2006; Andaloro, 2008), which therefore indicates trophic niche segregation in Synodus saurus.

In conclusion, the Atlantic lizardfish in the southern Tyrrhenian Sea is piscivorous: it feeds mainly on juveniles of others predators, so it can be considered an apex predator of the sandy bottoms of the continental shelf, exploring different habitats during its feeding activity and hunting various prey types, depending on resource availability and the size of prey.

\section{ACKNOWLEDGEMENTS}

We would like to thank the crewmembers of the fishing boat "Papà Carmelo". Thanks are due to Patrizia Perzia, Pierpaolo Consoli and Manuela Falautano for technical assistance, Emma Burton for the English revision of the text and Tomas Vega Fernandez for the Spanish summary.

\section{REFERENCES}

Andaloro, F. - 1994. Indagini sulle condizioni della fascia costiera della Sicilia settentrionale per la tutela, il ripopolamento e lo sfruttamento ottimale delle risorse biologiche. ICRAM Report, pp. 366.

Andaloro, F. - 2008. Studio della Surf-Zone in Tirreno meridionale attraverso l'analisi delle relazione trofiche tra benthos e comunità ittica. ICRAM Report, pp. 119.

Bauchot, M.L. - 1987. Poissons osseux. In: W. Fischer, M.L. Bauchot and M. Schneider (eds.), Fiches FAO d'identification pour les besoins de la pêche. (rev. 1). Méditerranée et mer Noire. Zone de pêche 37, Vol. II., pp. 891-1421. Commission des Communautés Européennes and FAO, Rome.

Brambati, A., G. Catani, M. Celio and E. Colizza. - 1995. Primi risultati delle ricerche sedimentologiche nel bacino di Gioia e sulle coste della Sicilia settentrionale tra la foce del Fiume Pollina ed il Capo Peloro. In: F.M. Faranda (ed.), Caratterizzazione ambientale marina del sistema Eolie e dei bacini limitrofi di Cefalù e Gioia (EOCUMM 94). Data Rep., 303-316.

Castriota, L., M.P. Scarabello, M.G. Finoia, M. Sinopoli and F. Andaloro. - 2005a. Food and feeding habits of pearly razofish, Xyrichtys novacula (Linnaeus, 1758), in the southern Tyrrhenian Sea: variation by sex and size. Environ. Biol. Fish., 72: 123-133.

Castriota, L., M.G. Finoia and F. Andaloro. - 2005b. Trophic interactions between Xyrichtys novacula (Labridae) and juvenile Pagrus pagrus (Sparidae) in the central Mediterranean Sea. Electr. J. Ichthyol., 2: 54-60.

Castriota, L., M.G. Finoia, S. Campagnuolo, C. Pipitone and F. Andaloro. - 2006. Diet of juvenile Pagrus pagrus (Sparidae) from sandy bottoms of the southern Tyrrenian Sea. Cybium, 30(4): 291-295.

Chessel, D. and J. Thioulouse. - 1996. L'analyse discriminante des correspondances. Documentation Themalique ADE-4, Vol. 5, Section 6. Univ. Claude Bernard - Lyon 1, Lyon.

Clarke, K.R. and R.M. Warwick. - 2001. Change in marine communities: an approach to statistical analysis and interpretation. $2^{\text {nd }}$ edition. PRIMER-E Plymouth.

Cruz-Escalona, V.H., M.S. Peterson, L. Campos-Dávila and M. Zetina-Rejón. - 2005. Feeding habits and trophic morphology of inshore lizardfish (Synodus foetens) on the central continental shelf off Veracruz, Gulf of Mexico. J. Appl. Ichthyol., 21: 525-530.

Ferry, L.A. and G.M. Caillet. - 1996. Samples size and data analysis: are we characterizing and comparing diet properly? In: D. MacKinley and K. Shearer (eds.), Feeding ecology and nutrition in fish. pp. 71-80, GUTSHOP'96, symposium proceedings of American Fisheries Society, San Francisco, CA. 
Golani, D. - 1993. The biology of the Red Sea migrant, Saurida undosquamis in the Mediterranean and comparison with the indigenous confamilial Synodus saurus (Teleostei: Synodontidae). Hydrobiologia, 271: 109-117.

Hacunda, J.S. - 1981. Trophic relationships among demersal fishes in a coastal area of the Gulf of Maine. Fish. Bull., 79: 775-788.

Hyslop, E.J. - 1980. Stomach content analysis: A review of methods and their application. J. Fish. Biol., 17: 411-422.

Kagiwara, F. and V. Abilhôa. - 2000. A alimentação do peixe-lagarto Synodus foetens (Linnaeus, 1766) em um banco areno-lodoso da Ilha do Mel, Paraná, Brasil. Arq. Ciên. Vet. Zool. Unipar, Umuarama, 3(1): 9-17.

Keenleyside, M.H.A. - 1979. Diversity and Adaptation in Fish Behaviour. Springer-Verlag, Berlin.

Matarrese, A., M. Panza and F. Mastrototaro. - 1996. Accrescimento di Spicara flexuosa (Rafinesque, 1810) nel mar Ionio. Biol. Mar. Medit., 3(1): 553-556.

Montalenti, G. - 1937. Maenidae. In: G. Bardi, R. Friedländer e Sohn (eds.), Fauna e flora del Golfo di Napoli: Uova, larve e stadi giovanili di Teleostei, 38(2-3): 383-390.

Paxton, J.R. - 1967. A distributional analysis for the Lanternfishes (Family Myctophidae) of the San Pedro Basin, California. Copeia, 2: 422-440.

Pinkas, L., M.S. Olipham and I.L.K. Iverson. - 1971. Food habits of albacore, bluefin tuna and bonito in Californian waters. Calif. Fish Game, 152: 1-105.

Scotto di Carlo, B., G. Costanzo, E. Fresi, L. Guglielmo and A. Ianora. -1982 . Feeding ecology and stranding mechanisms in two lanternfishes, Hygophum benoiti and Myctophum punctatum. Mar. Ecol. Prog. Ser, 9: 13-24.

Sousa, L., J.P. Barreiros, M.S.C. Soares, M. Hostim-Silva and R.S. Santos. - 2003. Preliminary notes on the reproductive biology of the lizardfish, Synodus saurus (Linnaeus, 1758) (Actynopterygii: Synodontidae) in the Azores. Cybium, 27(1): 41-45.

Soares, M.S.C., J.P. Barreiros, L. Sousa and R.S. Santos. - 2002. Agonistic and predatory behaviour of the lizardfish Synodus saurus (Linnaeus, 1758) (Actinopterygii: Synodontidae) from the Azores. Aqua, J. Ichthyol. Aquat. Biol., 6(2): 53-60.

Soares, M.S.C., L. Sousa and J.P. Barreiros. - 2003. Feeding habits of lizardfish Synodus saurus (Linnaeus, 1758) (Actinopterygii: Synodontidae) from the Azores. Aqua, J. Ichthyol. Aquat. Biol, 7(1): 29-38.

Sulak, K.J - 1986. Synodontidae. In: P.J.P. Whitehead, M.L. Bauchot, J.C. Hureau, J. Nielsen and E. Tortonese (eds.), Fishes of the North-eastern Atlantic and the Mediterranean, vol. 1, pp. 405-411. UNESCO, Paris.

Tramontana, M., P. Colantoni and F. Fanucci. - 1995. Risultati preliminari delle indagini morfologico-sedimentologiche condotte nell'ambito del progetto EOCUMM 94. In: F.M. Faranda (ed.), Caratterizzazione ambientale marina del sistema Eolie e dei bacini limitrofi di Cefalù e Gioa (EOCUMM 94). Data Rep., 331-338.

Scient. ed.: J.E. Cartes.

Received May 27, 2008. Accepted October 16, 2008.

Published online March 9, 2009. 